PERM JOURNAL OF PETROLEUM AND MINING ENGINEERING ВЕСТНИК ПНИПУ. ГЕОЛОГИЯ. НЕФТЕГАЗОВОЕ И ГОРНОЕ ДЕगО ISSN 2224-9923 Volume/ Tom 19 №1 2019

http://vestnik.pstu.ru/geo/

UDC 622.276:622.692.4.053:331.45

Article / Статья

(C) PNRPU / ПНИПУ, 2019

\title{
ABOUT THE STRUCTURE OF THE SYSTEM OF PHYSICAL PROTECTION OF MAIN PIPELINES AGAINST INTENDED THREATS
}

\section{Vladimir A. Komarov, Zinaida V. Semenova', Dmitrii A. Bronnikov, Aleksei A. Nigrei}

Omsk State Transport University (35, Marks ave., Omsk, 644046, Russian Federation)

${ }^{1}$ The Siberian State Automobile And Highway University (5, Mira ave., Omsk, 644080, Russian Federation)

\section{О СТРУКТУРЕ СИСТЕМЫ ФИЗИЧЕСКОЙ ЗАЩИТЫ МАГИСТРАЛЬНЫХ ТРУБОПРОВОДОВ ОТ ПРЕДНАМЕРЕННЫХ УГРОЗ}

\section{В.А. Комаров, 3.В. Семенова ${ }^{1}$, Д.А. Бронников, А.А. Нигрей}

Омский государственный университет путей сообщения (644046, Россия, г. Омск, пр. Маркса, 35)

${ }^{1}$ Сибирский государственный автомобильно-дорожный университет (644080, Россия, г. Омск, пр. Мира, 5)

Received / Получена: 10.09.2018. Accepted / Принята: 14.01.2019. Published / Опубликована: 29.03.2019

\section{Key words:}

main pipelines, unauthorized tieins, pumped product, emergency situations, methods for detecting and preventing product leaks, distributed fiber-optic systems, fighting artificial interference, multi-sensor system. \begin{abstract}
The statistics of emergency situations at pipeline transportation facilities indicates the presence of problematic issues during
transportation of products. In the structure of accidents of the past decade, theft of products ("mortise terrorism") prevailed, transportation of products. In the structure of accidents of the past decade, theft of products ("mortise terrorism") prevailed,
sabotage acts were recorded. The article presents data about the growth in the number of criminal interventions in the operation of pipelines, which pose a great danger to the health and life of the population, a threat to the environment, as they cause accidents, spills of oil and oil products, pollution of soil, rivers and water bodies, as well as associated environmental and economic losses from these criminal interventions. Illustrated the total losses incurred by the owner of the pipeline system from the attacks of intruders. The less the owner invests in ensuring the safety of the infrastructure, the greater losses should be expected during the operations.

The analysis of publication activity in the field of ensuring the safety of pipeline transport and the detection of unauthorized actions in the protection zone was carried out, which showed that the research is mainly focused on creating a system of physical protection of pipelines that implements the principle of "do not miss the attacker's contact with the shell of the pipe". The main direction of research to counter these threats is focused on the detection of disturbances of the seismic field in the security zone of the pipeline using a fiber-optic cable (sensor). In addition to distributed fiber optic systems for the preventive neutralization of terrorist threats to extended objects, the capabilities of video-analytical and thermal imaging systems were evaluated.

The structure of the system of physical protection of pipelines for the detection and neutralization of unauthorized tie-ins into the pipe in order to minimize the level of losses during pipeline security is proposed.

Demonstrated the effectiveness of the proposed approach to determining the requirements for systems to protect objects from terrorist threats.
\end{abstract}

Статистика чрезвычайных ситуаций на объектах трубопроводного транспорта свидетельствует о наличии проблемных вопросов при транспортировке перекачиваемых продуктов. В структуре аварий прошедшего десятилетия преобладали хищения этих продуктов («врезной терроризм»), зафиксированы диверсионные акты. В статье приведены данные о росте числа криминальных вмешательств в работу магистральных трубопроводов, представляюших огромную опасность для здоровья и жизни населения, угрозу окружаюшей среде, так как они являются причиной аварий, разливов нефти и нефтепродуктов, загрязнения почвы, рек и водоемов, а также сопутствующих экологических и экономических потерь. Проиллюстрированы суммарные потери, которые несет собственник трубопроводной системы от нападений злоумышленников. Чем меньше средств он вкладывает в обеспечение безопасности созданной инфраструктуры, тем больших потерь следует ожидать при ее эксплуатации. Проведен анализ публикационной активности в области обеспечения безопасности трубопроводного транспорта и обнаружения несанкционированных действий в охранной зоне, который показал, что исследования в основном сконцентрированы на создании системы физической защиты магистральных трубопроводов, реализующей принцип «не пропустить контакта злоумышленника с оболочкой трубы». Основное направление исследований по противодействию указанным угрозам ориентировано на обнаружение возмущений сейсмического поля в охранной противодействию указанным угрозам ориентировано на обнаружение возмущений сейсмического поля в охранной зоне трубопровода с помощью волоконно-оптического кабеля (датчика). Помимо распределенных оптоволоконных
систем для превентивной нейтрализации террористических угроз протяженным объектам оценивались возможности видеовиброаналитических и тепловизионных систем.

Предложена структура системы физической защиты магистральных трубопроводов для обнаружения и нейтрализации несанкционированных врезок в трубу в целях минимального уровня потерь при охране трубопровода.

Продемонстрирована эффективность предложенного подхода по определению требований к системам защиты объектов от террористических угроз.

\footnotetext{
Vladimir A. Komarov (Author ID in Scopus: 57197211324) - PhD student of the Department of Information Security (e-mail: reallkom@gmail.com)
Zinaida V. Semenova - Doctor of Education, Professor, Head of the Department of Information Security (e-mail: zvs111@gmail.com).

Zinaida V. Semenova - Doctor of Education, Professor, Head of the Department of Information Security (e-mail: zvs111@gmail.com).

Dmitrii A. Bronnikov (Author ID in Scopus: 57200729064) - PhD student of the Department of Information Security (e-mail: dmi-bronnikov@yandex.ru).
Aleksei A. Nigrei (Author ID in Scopus: 57200720879) - PhD student of the Department of Information Security (e-mail: nigrey.n@mail.ru). The contact person
} for correspondence.

Комаров Владимир Александрович - аспирант кафедры информационной безопасности (тел.: +007 913 631 00 57, e-mail: reallkom@gmail.com). Семенова Зинаида Васильевна - доктор педагогических наук, профессор, заведующий кафедрой информационной безопасности (тел.: +007 9136159758 , e-mail: zvs111@gmail.com)

Бронников Дмитрий Алексеевич - аспирант кафедры информационной безопасности (тел.: +007 929365 85 37, e-mail: dmi-bronnikov@ yandex.ru).

Нигрей Алексей Андреевич - аспирант кафедры информационой безопасности (тел.: + 00791363850 02, e-mail: nigrey.n@mail.ru). Контактное лицо для переписки. 


\section{Introduction}

The pipeline transport is one of the safest, reliable, efficient, cost-effective methods for continuously transporting an unlimited products flow over long distances, regardless of the weather. The total length of Russian pipelines for 2018 is about 285 thousand $\mathrm{km}$. However, the emergency situations statistics at pipeline transport facilities indicates the presence of problematic issues. As aging pipelines begin to fail, there are leaks. Along with the traditional emergencies causes: corrosion, natural effects, personnel errors, external influences began to play a significant role (Table) [1].

Information on the pipelines accidents causes in various regions of the world

\begin{tabular}{|l|c|c|c|c|c|c|c|c|c|c|c|c|}
\hline \multirow{2}{*}{$\begin{array}{l}\text { Country } \\
\text { (region) }\end{array}$} & \multicolumn{8}{|c|}{ Causes of accidents on the oil/gas pipelines } \\
\cline { 2 - 14 } & $\begin{array}{c}\text { External } \\
\text { influences }\end{array}$ & \multicolumn{2}{|c|}{$\begin{array}{c}\text { Equipment } \\
\text { defects }\end{array}$} & \multicolumn{2}{c|}{ Corrosion } & \multicolumn{2}{c|}{$\begin{array}{c}\text { Natural } \\
\text { influences }\end{array}$} & \multicolumn{2}{c|}{$\begin{array}{c}\text { Personnel } \\
\text { errors }\end{array}$} & \multicolumn{2}{|c|}{ Other } \\
\cline { 2 - 15 } & abs. & $\%$ & abs. & $\%$ & abs. & $\%$ & abs. & $\%$ & abs. & $\%$ & abs. & $\%$ \\
\hline Russia & 63 & 17 & 19 & 30 & 6 & 50 & - & - & 12 & 3 & - & - \\
\hline USA & 23 & 25 & 20 & 19 & 23 & 23 & 4 & 10 & 7 & 2 & 23 & 21 \\
\hline $\begin{array}{l}\text { Western } \\
\text { Europe }\end{array}$ & 37 & 50 & 25 & 16 & 28 & 15 & 3 & 7 & 7 & 5 & - & 7 \\
\hline
\end{tabular}

There are other reasons that lead to leaks, such as accidental damage to the pipeline, acts of terrorism, sabotage, unauthorized tapping in order to steal the product, etc. According to statistics, approximately $63 \%$ of all cases are leaks arising from underground gas pipelines, $27 \%$ are damages to the onshore part of the pipeline, $10 \%$ are cases of underwater pipe ruptures.

One of the most urgent and difficult problems of pipelines operation is to detect unauthorized tie-ins and preventing of oil theft [2]. One of the main causes of accidents on Russian oil pipelines is unauthorized tieins and sabotage $(69.1 \%)$, as a result of which an oil spill occurs, the pipelines are impaired, which leads to a reduction in their service life, significant economic damage is caused, and preconditions for environmental disasters are created. [3].

Over the past 10 years, almost 4000 unauthorized tie-ins have been identified in Russia, which is $70 \%$ of all crimes related to the oil and its products theft. Thus, according to preliminary estimates, already in January-March 2018, attackers stole more than 18.5 thousand tons of oil to the amount of over 400 million rubles.

The graph of the number of committed illegal tie-ins into mainlines in Russia (2012-2017) is shown in Figure 1 [4].

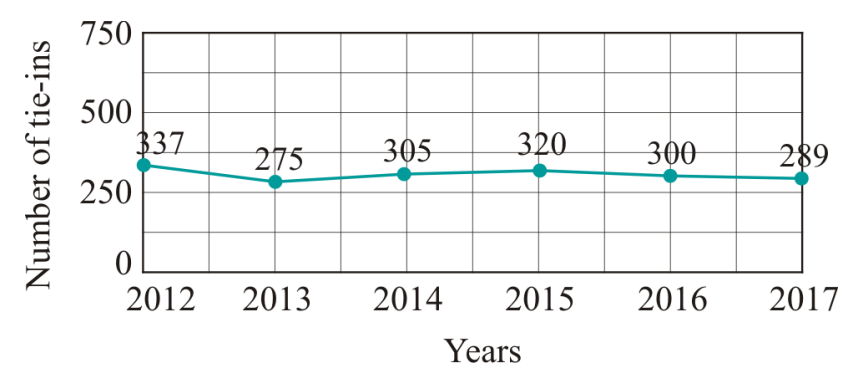

Fig. 1. Dynamics of illegal tie-ins into the mainlines of Russia for the period from 2012 to 2017

Criminal interventions in the minelines operation create a huge danger to the health and life of the population and a threat to the environment, as they cause accidents, oil and oil products spills, soil, rivers and water pollution [5]. The most dangerous consequences are the gas pipelines ruptures, since they can cause a shutdown of gas supply to entire regions. However, even after a complete shutdown of the gas supply facility, there is a risk of the explosion or a gas leak, which may cause environmental pollution.

Accidents lead to the leakage of oil products, gas from pipelines, which represent a serious danger to people, the environment, causing enormous economic and environmental damage. The dynamics of environmental damage on the mainlines of Russia for the period from 2012 to 2016 is presented in Fig. $2[6,7]$. 
In recent years, the rate of accidents on mainlines both in Russia and the USA has stabilized at around 0.1 accidents per year per $1000 \mathrm{~km}$ for gas pipelines and about $0.1-0.4$ accidents per year per $1000 \mathrm{~km}$ for oil and product pipelines. The press secretary of Greenpeace Russia in his publication (February 2018) indicated that more than 10 million barrels of oil are spilled in Russia annually. This is two times more than in the Gulf of Mexico accident [8].

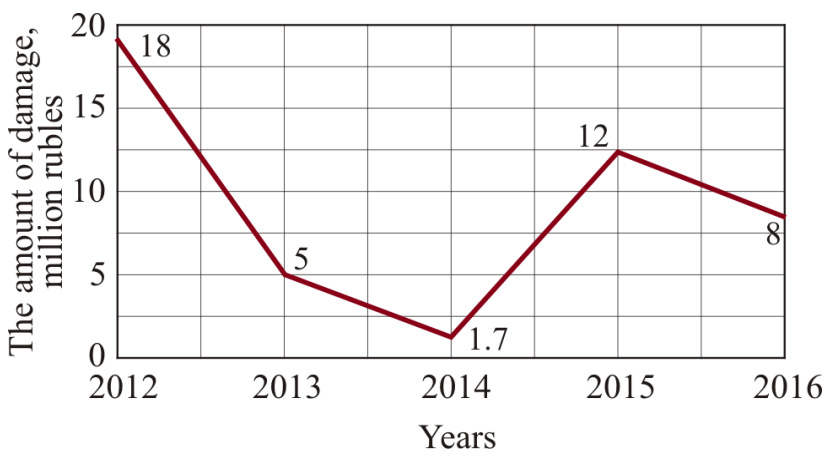

Fig. 2. Dynamics of environmental damage from accidents on the mainlines of Russia from 2012 to 2016

In the XXI the pipeline transport worn out by 50-70 \%. According to the estimates of EMERCOM of Russia specialists, more than $20 \%$ of mainlines and more than $40 \%$ of field pipelines are more than 30 years old, although the trouble-free use period is 10-20 years [9]. All this leads to the fact that Russia annually loses billions of dollars.

The main cause of accidents on gas pipelines in the USA is equipment defect (27 \%) and pipe corrosion (24\%). In Russia the number of accidents caused by pipe corrosion is $49 \%$, equipment defects $32 \%$. For oil pipelines in the last decade, the main cause of accidents is external exposure $-60 \%$ of cases, while in the US it is only $20 \%$ [10].

The authors [11] analyzed the publication activity in the field of pipeline transport safety ensuring and of unauthorized actions detection in the security zone. The analysis showed that the research is mainly focused on the creation of a physical protection system for mainlines that implements the principle of "not to miss the attacker's contact with the pipe shell". The authors of [11] found that over the past few years a significant number of publications on this topic have been presented in international databases: more than 80 publications in the Web of Science database, more than 60 publications in Scopus. Analysis of publications in the RISC database for 5 years (2012-2016) showed more than 90 papers about the pipeline safety problem.

The results of studies on the product leaks detection in oil and gas pipelines are summarized in $[12,13]$. It can be stated that the main interest of foreign researchers is concentrated on the development of seismic (57 \%), optical $(23 \%)$ and vibro-acoustic (14\%) methods for product leaks detecting and preventing. The development of seismic methods focuses on improving signal processing algorithms ( $58 \%), 27 \%$ of publications are devoted to analyzing the capabilities of various sensors, the remaining $15 \%$ can be attributed to the description of detection objects and test results of the proposed systems.

Considerable attention is paid to the use of fiber-optic cable as a sensor for measuring the temperature distribution and mechanical stresses in the surrounding environment. Local inhomogeneities of these indices lead to Raman scattering of the pulse transmitted via an optical cable (Raman, Mandelstam Brillouin, etc.). The location of these inhomogeneities is judged by the propagation time of the scattering components from the site (the principle of active radar) [14-16]. Fiber optic sensors for the oil and gas industry are manufactured by Weatherford, BakerHughes, Halliburton, Schlumberger, as well as the Russian enterprises Omega, Optolink, Intel-Systems. The principle of detecting external impacts (mechanical 
stresses) and leakage (local temperature changes of the environment) is the basis for the Omega leak detection and activity control system (LDACS) developed by PJSC "Transneft", which analyzes changes in temperature field and detects leaks of gas, oil and other liquids as well as in multiphase pipelines with an accuracy of up to $5 \mathrm{~m}$ [17]. Another security fiber-optic system of a similar purpose, the Dunay, which has undergone numerous field tests at Gazprom facilities, allows you to record the movement of a pedestrian and manual digging directly above the cable [18]. When a person or car approaching, or when work near a protected object, the system records and transmits information to the operator's computer about the approximation with an accuracy of 10 meters. According to the results of the foreign developments tests used to detect terrorist attacks on extended objects, it can be concluded that all issues have been resolved $[15,19]$. However, in the presence of noise of natural and artificial origin, the efficiency of these systems is not clear. This circumstance led to the following conclusions:

- «In the open literature, no reliable data was found on the satisfactory operation of such systems over extended (over $10 \mathrm{~km}$ ) objects» [18];

- «For further improvement of the method, research work is needed, $<\ldots>$ as well as the development of data processing techniques» [20];

- «Fiber-optic methods for detecting leaks in pipelines $\langle\ldots\rangle$ require serious improvements. $<\ldots>$ In difficult seismically active conditions, there is a need for combined use with thermal vibration methods ...» [21].

\section{Noise factor}

A sign of a terrorist attack is the intrusion into the security zone and the formation of a pit for contact with the pipe shell. Seismic vibrations are formed at the site of the soil deformation, which, upon reaching the fiberoptic cable, causes it to deform. In the upper soil layer, the velocity of the longitudinal waves and the absorption coefficient are approximately proportional to the square root of the oscillation frequency. Depending on water saturation, soil porosity, etc. the speed of these waves can vary by more than 10 times. For these reasons, the shape of the recorded disturbances can change significantly during the day. This circumstance makes it difficult to use these detection methods in the noise background.

The amplitudes of natural seismic noise are at a level of $1 \mu \mathrm{m}$ [22] and are comparable with the amplitude of the signals to be detected (Fig. 3).
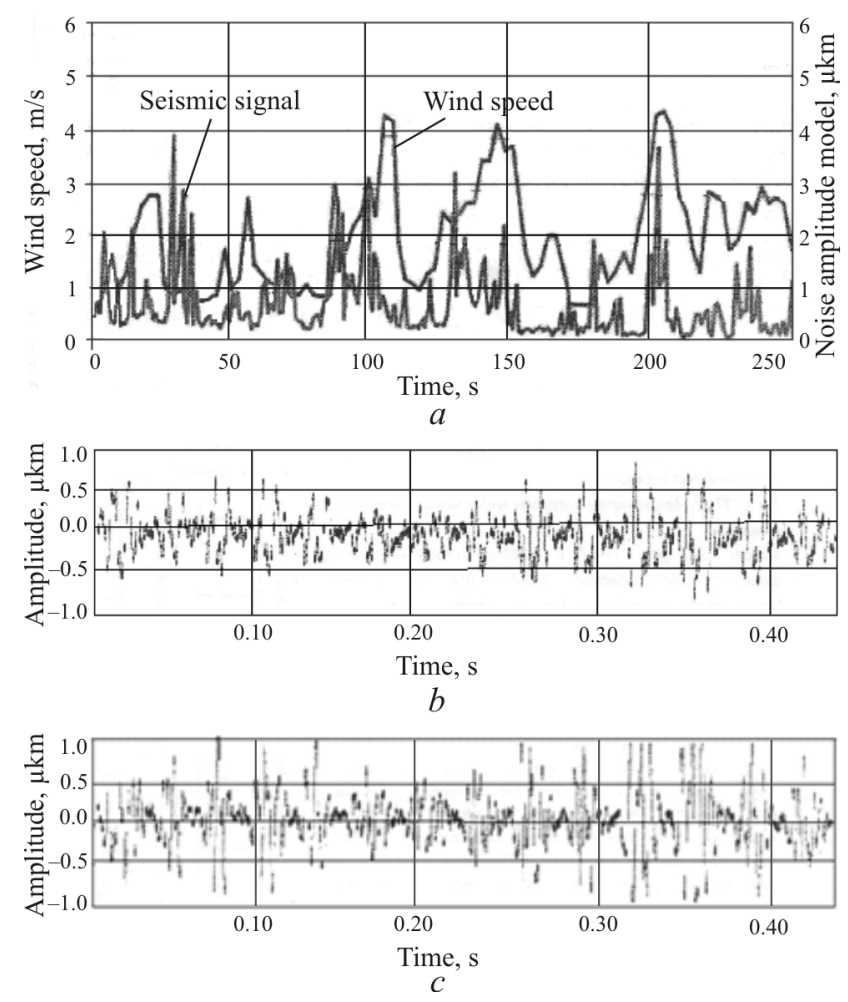

Fig. 3. Register of wind speed and seismic noise module in open areas (grass height $0.2 \mathrm{~m}$ ) at a distance of $7 \mathrm{~m}$ from the forest belt $(a)$; type of signals "shovel digging" at a distance of $9 \mathrm{~m}$ from the sensor along the horizontal $(b)$ and vertical $(c)$ axes 
This circumstance determined the appearance of conclusions like "... analysis of data from a distributed fiber-optic sensor is complicated by a high level of interference" [23]. To combat the interference accumulation techniques are used, filtration. The most widespread wavelet filtering, this allows to reduce the noise level in all frequency ranges. Most foreign studies are focused on the development of this area.

In [24] it is argued that the detection of Raman scattering signals against the noise background was ineffective. The use of wavelet noise cleaning has increased the signal-to-noise ratio by $11 \mathrm{~dB}$. The work [25] is devoted to the fight against environmental noise affecting the indices of phase-sensitive reflectometry (phiOTDR) during the detection and localization of dynamic excitations. It is argued that using the "specific" spectral analysis, the probability of correct detection can be increased to $94 \%$, and the level of false alarms - up to $6 \%$. Are these numbers acceptable?

The existing approach to assessing the required indicators of security systems is formed on the basis of expert technologies. Probability of correct detection $0.8 ; 0.9 ; 0.97$ recognized as low, medium and high "signaling" reliability. As regards the noise immunity of the method, one false response for 100 hours or less on a section 250 meters long is considered unsatisfactory. In this case, the flow of false alarms in the $2.5 \mathrm{~km}$ section exceeds the limit beyond which the security service stops responding to them. High noise immunity is considered to be 1 false response for 1,300-2500 hours on a site served by a separate guard group. The published figures on the noise immunity of mainlines monitoring systems do not reflect this aspect of the problem, and there is a need to fill this gap.

It is advisable to solve this issue not with the use of expert technologies, but based on the principle of minimizing the amount of losses from terrorist attacks and the cost of protecting the facility [26].

Another feature of the pipeline safety ensuring is the need to take into account the interaction of two opposing groups. The crimes are committed by well-organized structures that "... are generously spent on bribing the right people, training their specialists, ... buying special means to actively counteract the police and the security service ..." [27]. The technology of hiding the abducted product by pumping water into the pipeline in a volume equal to that taken is one of the examples of the "inventiveness" of the attacker. The patent and periodical literature describes many proposals for masking vibroacoustic signals. The industry produces a wide range of vibration generators to realize these goals. Installing a generator that generates seismic signals "excavation", under the soil layer in the security zone, creates serious problems for the security service [28]. Unfortunately, this aspect is not given due attention. One of the ways to solve it is discussed below.

\section{Multisensor system}

In the field of critical facilities protection, a list of rules has been formed that should be followed when designing physical systems for safety ensuring $[28,29]$. One of them: if the detection system used does not solve the problem with the required reliability, it is necessary to integrate other ones with different physical principles of response. To counteract the attacker a combination of two, three interacting systems should be used. If two of them are characterized by the detection probabilities $P_{1}$ and $P_{2}$, then the final probability will be

$$
P_{0}=P_{1}+P_{2}\left(1-P_{1}\right),
$$

with $P_{1}=P_{2}=0,8, P_{0}=0,96$. This rule is widely used abroad in the design of so-called multisensor perimeter protection systems [30]. 
In addition to distributed fiber optic systems for the preventive neutralization of terrorist threats to extended objects, the capabilities of video-analytical and thermal imaging systems were evaluated.

Video analytics is the technology of video data computer analysis in order to make a decision about the state of an object without human participation. Results achieved so far: when using a camera with a resolution of $640 \times 480$ pixels, observation can be conducted on an area of up to $200 \mathrm{~m}$ while snow with an intensity of up to $0.5 \mathrm{~mm} / \mathrm{h}$ and wind speeds of up to $8 \mathrm{~m} / \mathrm{s}$ on dynamic natural backgrounds. The probabilities of a target missing and false alarm according to test results were $0.041 \pm 0.003$ and $0.003 \pm 0.001$, respectively [31]

The vibroanalytical method is based on the excitation of elastic vibrations in the tube shell with the subsequent analysis of the registered signals at a given distance from the place of their excitation [32]. When waves propagate through the shell of a buried pipeline due to a significant difference in the wave resistance of the metal and gas, the re-emission of the energy of the signal into the pumped product is negligible (with a normal incidence of the longitudinal wave at the steel-air border (air-steel), only $0.002 \%$ of energy is reemitted, but a significant proportion of it goes into the surrounding soil). Due to the energy leakage into the pumped liquid, the damping of the propagating oscillations in their shell will be greater than in gas pipelines (about $12 \%$ of the oscillation energy passes through the "water - steel" border and into the surrounding soil). When the soil parameters change in a local area (oil output, soil removal, etc.), local energy re-emitions of the propagating through the shell signal are formed. In [31], a conclusion was made about the potential possibility of detecting changes in the state of the pipe by $0.01 \%$ in the form of a registered signal and this possibility was demonstrated in an experiment in identifying a formed pit and an ammunition mounted on a pipe, etc. In [33], it was shown that a local change in physical parameters in the near-tube space is better detected by the "ringing" signals energy increment, rather than by a change in their shape. Module "generator-receiver" allows you to control pipeline sections of a length of $2 \mathrm{~km}$ or more. Piezoceramic vibrators in the form of flexible surface linings of various shapes [34] are widely used to excite elastic waves in the tube shell.

The technology of underground pipelines diagnostics for thermal radiation from aircraft is considered in [35]. Even small cracks in the pipes lead to the appearance of thermal anomalies on the soil surface, which allow localization of the leakage place by an remote operating vehicle (ROV) [36]. Estimates are obtained for the density of false decisions when detecting hidden objects of various shapes along the pipeline route. The sharp decline in the cost of air monitoring of the pipeline when using ROV (10 times or more compared to using helicopters) made it possible to talk about the prospects of this technology. Experiments to detect leaks from pipelines in the thermal range of optical radiation are described in $[37,38]$ and others. The creation of a thermal 3D-model of fields above the buried pipeline [39] is being completed, and Transneft, JSC has shown interest in using it" [40]. The question was also raised about the need to ensure a qualitatively new level of reliability of oil pipelines. The question was also raised about the need to ensure a qualitatively new level of reliability of oil pipelines under the conditions of terrorist threats. PJSC Trans-Neft is «aims "...to create integrated security systems that can be controlled from a single center"» [40]. 
The creation of complex systems is based on the use of the Saaty hierarchy analysis method [29]. Given the specificity of the task, it is necessary to have specific data on the socio-economic situation and the "moral" health of the population in the country in the current period and in the near future [26]. However, in the simplest version of the solution of this problem, we can confine ourselves to the following example.

Figure 4 illustrates the losses incurred by the owner of the pipeline system from attacks. The less he invests in ensuring the safety of the created infrastructure, the more losses should be expected during its operation.

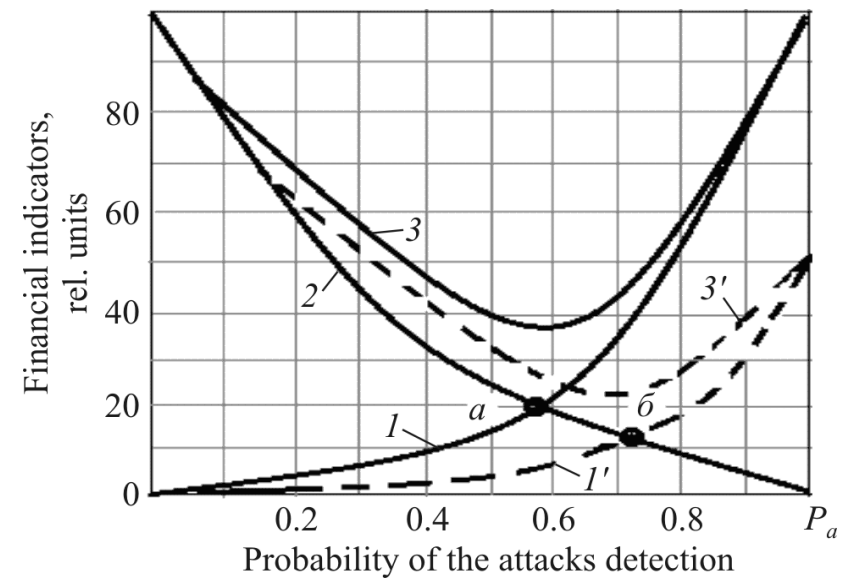

Fig. 4. Financial indicators depending on the probability of detecting attacks of $P_{a}: 1$ (1) protection costs when using singlesenory (1) and multisensory (1') systems; 2 - damage from missed attacks; $3(3)$ - the total loss of the object by using singlesenory (3) and multisensory (3) systems

The point of minimum total loss determines the required probability of detection $-\mathrm{Pa}$. The object owner is aware of the costs of its protection and losses from missed attacks. In this way, it is possible to assess the direction of the countermeasure system improving to ensure the optimal value of the indicated probability. However, one should keep in mind the dependence of the position and shape of the curves in Fig. 4, reflecting expenditure items, from many factors, the dynamics of their change exceeds the ability to modernize the existing counteracting systems in accordance with the requirements of the current moment [5].

An analysis of publications over the past decade allows us to conclude that the technology of detecting activity in the protected zone, implemented using a distributed fiber-optic sensor, will be used as the basis for ensuring the safety of mainlines from terrorist threats in the near future. Therefore, care should be taken to neutralize false signals, especially in the conditions of the creation of artificial interference in the security zone.

To date, a point of view has emerged on the need to supplement fiber-optic detection systems by one of the above-mentioned subsystems. The requirements for each of the subsystems are adjusted. In accordance with the recommendations of [15], the length of a separate zone based on a fiber-optic sensor should be about $40 \mathrm{~km}$. The detector based on it is designed to ensure a high probability of being correctly located, including by increasing false signals. The task of the system interacting with it is to check which of the incoming solutions is correct, and not the right.

\section{Concluions}

Video analytic, vibroacoustic and thermal imaging systems can be used in various combinations with the basic detector and among themselves. The simplest combination: "fiber optic channel - vibroanalytical channel security service". For each link of the first type will need at least 10 links of the second type. Energy consumption for the operation of a vibroanalytical link is of the order of $0.5 \mathrm{~J}$. Therefore, it is included in the work by signals of the "appearance of an intruder" coming from the first link. If the density 
of false decisions from the fiber-optic detection system is $\leq 1 h-1$, the problem of energy efficiency of this type of multisensor system is solved. Considering that, in accordance with the theoretical analysis, the probability of false decisions of the second link (removal of a part of the soil surrounded by the pipeline) tends to zero, after a period of time to create a pit, the considered system will satisfy the detection reliability.

\section{References}

1. Epifantsev B.N., Piatkov A.A., Fedotov A.A. Kontseptsiia obespecheniia bezopasnoi raboty magistralnykh truboprovodov $\mathrm{V}$ usloviiakh vneshnikh vozdeistvii [Concept of ensuring operation of the main trunk lines under the conditions of external effects]. Bezopasnost truda v promyshlennosti, 2013, no.12, pp.42-49.

2. Tsviak A.V. Ekologicheskie posledstviia nesanktsionirovannykh vrezok v nefteprovody i metody borby s nimi [Environmental impact unapproved inserts in the pipeline and methods of combating them]. Vestnik Orenburgskogo gosudarstvennogo universiteta, 2015, no.10 (185), pp.445-447.

3. Vtorushina A.N., Anishchenko Y.V., Nikonova E.D. Risk assessment of oil pipeline accidents in special climatic conditions. IOP Conf. Series: Earth and Environmental Science 66 (2017) 012006. Ecology and safety in the technosphere: All-Russian research-to-practice conference, Yurga, 2017. DOI: $10.1088 / 1755-1315 / 66 / 1 / 012006$

4. Nelegalnye vrezki v nefteprovody ostaiutsia ne reshaemoi problemoi dlia pravookhranitelei i zakonodatelei [Illegal cuttings in the oil pipeline remain an unresolved problem for law enforcers and legislators], available at: hpps://versia.ru/ nelegalnye- vrezkiv-nefteprovody-ostayutsya-ne-reshaemoj-problemoj-dlya-pravooxranitelej-i-zakonodatelej/ (accessed 10 August 2018).

5. Komarov V.A., Semenova Z.V., Mikhaylov E.M., Nigrey A.A., Bronnikov D.A. Security of major pipelines in presence of terroristic threats: prognostic estimates. Perm Journal of Petroleum and Mining
Engineering, 2018, vol.17, no.1, pp.88-100. DOI: $10.15593 / 2224-9923 / 2018.1 .8$

6. Godovoi otchet o deiatelnosti Federalnoi sluzhby po ekologicheskomu, tekhnologicheskomu $\mathrm{i}$ atomnomu nadzoru v 2016 godu [Annual report on the activities of the Federal Service for Environmental, Technological and Nuclear Supervision in 2016]. Moscow, 2017, 397 p.

7. Proekt doklada o pravoprimenitelnoi praktike kontrolno nadzornoi deiatelnosti $\mathrm{V}$ federalnoi sluzhbe po ekologicheskomu, tekhnologicheskomu i atomnomu nadzoru pri osushchestvlenii federalnogo gosudarstvennogo nadzora v oblasti promyshlennoi bezopasnosti za 2017 god [Draft report on law enforcement practice of supervisory activities in the Federal Service for Environmental, Technological and Nuclear Supervision in the implementation of federal state supervision in the field of industrial safety for 2017]. Moscow, 2018, 66 p.

8. Fomin K. Skolko nefterazlivov slishkom mnogo dlia Britanskogo muzeia? [How many oil spills - are too much for the British Museum?], available at: http://www.greenpeace.org/russia/ru/news/ blogsgreen-planet/blog/61117/ (accessed 10 August 2018).

9. $\mathrm{V}$ reshenii problemy razlivov nefti nametilsia progress [Progress has been made in solving the problem of oil spills], available at: http:/www.greenpeace.org/russia/ru/news/ 2018/oil- 0323/ (accessed 10 August 2018).

10. Savina A.V. Analiz riska avarii pri obosnovanii bezopasnykh rasstoianii ot magistralnykh truboprovodov szhizhennogo 
uglekislogo gaza do obektov $\mathrm{s}$ prisutstviem liudei [Analysis of the risk of accidents in the justification of safe distances from the main pipelines of liquefied carbon dioxide to objects with the presence of people]. $\mathrm{Ph}$. D. thesis. Moscow, 2013, 121 p.

11. Bronnikov D.S., Semenova Z.V., Borisov R.V., Komarov V.A., Nigrei A.A., Zhumazhanova S.S., Nigrei N.N. Model formirovaniia teplovykh izobrazhenii podstilaiushchei poverkhnosti okhrannykh zon magistral'nykh produktoprovodov [Model of thermal imaging of the underlying surface of the trunk pipelines protected zones]. Otchet o NIR (zakliuchitelnyi) no. ГР 115050610098.Omsk, 2017, 217 p.

12. Lou Z., Liu H., Hu M. A general survey on technological developments of oil leakage detection over the past decade. Applied Informatics and Communication, 2011, vol. 31, pp. 16-22. DOI: 10.1007/978-3-642-23214-5_79

13. Wang L. et al. Summary of detection and location for oil and gas pipeline leak. 25 th Chinese Control and Detection Conference, 2013, no.656, pp.821-826. DOI: 10.1109/CCDC.2013.6561035

14. Nikles M., Vogel B., Briffod F., Grosswig S., Sauser F., Luebbecke S., Bals A., Pfeiffer T. Leakage detection using fiber optics distributed temperature monitoring. $11^{\text {th }}$ SPIE Annual International Symposium on Smart Structures and Materials, March 14-18, 2004, San Diego, 2004, vol. 5384, pp. 18-25. DOI: $10.1117 / 12.5400270$

15. Duckworth G.L., Ku E.M. OptaSense (R) distributed acoustic and seismic sensing using COTS fiber optic cables for Infrastructure Protection and Counter Terrorism. Sensors, and command, control, communication, and intelligence (C3I) Technologies for homeland Security and homeland defense, 2013, XII. vol.8711, no.UNSP 871106. DOI: $10.1117 / 12.2017712$

16. Duan L. Thermal noise-limited fiberoptic sensing at infrasonic frequencies. IEEE
Journal of Quantum Electronics, 2015, vol.51, no.2, pp.1-6. DOI: 10.1109/JQE.2014.2384914

17. Suvorova E. Vne zony dostupa [Out of range]. Truboprovodnyi transport nefti, 2012, no.6, pp.34-35.

18. Nesterov E.T., Marchenko K.V., Treshchikov V.N., Leonov A.V. Volokonnoopticheskaia sistema monitoringa protiazhennykh obektov (nefteprovodov) na osnove kogerentnogo reflektometra [Fiber optic system for monitoring extended facilities (oil pipelines) using a coherent reflectometer]. T-Comm: telekommunikatsii $i$ transport, 2014, no.1, pp.25-28.

19. Klar A., Linker R. Fiber optic sensing optical fibers detect funnel-digging. Laser Focus World: Laser, Photonics, Optics News \& Technology Advances, 2009, available at: http://www.laserfocusworld.com/articles/ print/volume-45/issue-4/world-nws/fiber-opticsensing-optical-fibers-detect-tunnel-digging.html/ (accessed 10 August 2018).

20. Shekhovtsov A.V., Mansurov M.N., Golubin S.I. Eksperimentalnoe issledovanie volokonno-opticheskogo metoda obnaruzheniia utechek iz neftegazoprovodov [Experimental studies of fiber-optic method of detecting leaks in oil and gas pipelines]. Truboprovodnyi transport: teoriia i praktika, 2015, no.6 (52), pp.30-35.

21. Shestakov R.A., Ganeeva L.K., Ganeeva L.K. Analiz volokonno-opticheskikh metodov obnaruzheniia utechek v truboprovodakh [Analysis of fiber-optic leak detection system in pipeline]. Trudy $R G U$ nefti $i$ gaza imeni I.M. Gubkina, 2015, no.2 (279), pp.56-64.

22. Koridalin V.E. et al. Seismicheskie shumy industrialnogo goroda [Seismic noise of an industrial city]. DAN SSSR, 1985, vol.280, no.5, pp.1094-1097.

23. Kuznetsov V.A., Tsukanov V.N., Iakovlev M.Ia. Volokonno-opticheskie informatsionno-izmeritelnye sistemy [Fiber- 
optical information measuring systems]. Vysokie tekhnologii $v$ promyshlennosti rossii (materialy $i$ ustroistva funktsionalnoi elektroniki $i$ mikrofotoniki). Materialy XII mezhdunarodnoi nauchno-tekhnicheskoi konferentsii. Moscow, OAO TSNITI "Tekhnomash", 2006, pp.342-349.

24. Wang J., Han J. A New noise suppression algorithm for optical fiber temperature surveillance of heavy oil thermal recovery well. International Conference on Optical Instruments and Technology: Optical Sensors and Applications, 2011, vol.8199, no.81991. DOI: $10.1117 / 12.906604$

25. Wu H., Li X., Peng Z. A novel intrusion signal processing method for phasesensitive optical time-domain reflectometry (Phi-OTDR). 23RD International conference on Optical Fibre Sensors, 2014, vol.9157, no.91573. DOI: $10.1117 / 12.2058503$

26. Epifantsev B.N., Piatkov A.A. Preduprezhdenie chrezvychainykh situatsii na magistralnykh produktoprovodakh. Part 1. Obnaruzhenie nesanktsionirovannykh vtorzhenii v okhrannuiu zonu produktoprovoda [Prevention of emergency situations on trunk pipelines. Part 1. Detection of unauthorized intrusions into the security zone of the pipeline]. Omsk, Izdatelstvo SibADI, 2013, 122 p.

27. Onopriiuk V. Angarskii izlom [Ангарский излом]. Truboprovodnyi transport nefti, 2013, no.6, pp.32-38.

28. Zvezhinskii S.S. Perimetrovye maskiruemye seismicheskie sredstva obnaruzheniia [Perimeter masked seismic detection tools]. Spetsialnaia tekhnika, 2004, no.3, pp.26-37.

29. Borovskii A.S., Tarasov A.D. Obshchaia matematicheskaia model sistemy fizicheskoi zashchity obektov [General mathematical model of the system of physical protection of objects]. Vestnik kompiuternykh $i$ informatsionnykh tekhnologii, 2011, no.10, pp.2-29.
30. Dulski R. et al. Concept of data processing in multi-sensor system for perimeter protection. Conference of Sensors, and Command, Control, Communications, and Intelligence (C3I) Technologies for Homeland Security and Homeland Defence X, 2011, vol.8019, no.8019-35. DOI: 10.1117/12.883965

31. Epifantsev B.N., Piatkov A.A., Kopeikin S.A. Multisensornye sistemy monitoringa territorii ogranichennogo dostupa: vozmozhnost videoanaliticheskogo kanala obnaruzheniia vtorzhenii [Multi-sensor systems for monitoring access to restricted areas: capabilities of the intrusion detection video analytical channel]. Kompiuternaia optika, 2016, vol.40, no.1, pp.121-129. DOI: 10.18287/2412-6179-2016-40-1-121-129

32. Epifantsev B.N. An acoustic method for diagnostics of the state of underground pipelines: new possibilities. Russian Journal of Nondestructive Testing, 2014, vol.50, no.5, pp.254-257. DOI: $10.1134 / \mathrm{S} 1061830914050039$

33. Epifantsev B.N., Pyatkov A.A., Fedotov A.A. Evaluation of the sensitivity of a vibroacoustic detection system for local disturbances of trunk pipeline environmental parameters. Russian Journal of Nondestructive Testing, 2015, vol.51, no.2, pp.70-78. DOI: $10.1134 / \mathrm{S} 1061830915020035$

34. Giurgintin V. Structural health monitoring with piezoelectric wafer active sensors. New-York, Academic Press, 2007, $760 \mathrm{p}$.

35. Epifantsev B.N. Distantsionnaia diagnostika podzemnykh truboprovodov po teplovomu izlucheniiu [Remote diagnostics of underground pipelines for thermal radiation]. Defektoskopiia, 2014, no.3, pp.28-39.

36. Vragova E.V., Skliarov L.A. Obnaruzhenie utechek gaza iz magistralnykh gazoprovodov $\mathrm{v}$ teplovom pole izlucheniia zemnoi poverkhnosti [Detection of gas leaks 
from gas pipelines in the thermal field of radiation of the earth's surface]. Vestnik $N G U$. Seriia: Informatsionnye tekhnologii, 2009, no.4, pp.73-80.

37. Mucsi L. Application of GIS and aerial thermal image processing methods to solve environmental problems of the oil industry, available at: http://www.geo.u-szeged.hu/ web/sites/default/files/publikaciok/ML/57.pdf/ (accessed 10 August 2018).

38. Kretov L.T. et al. Videoteplovizionnyi kontrol sostoianiia gazoprovodov $\mathrm{s}$ ispolzovaniem sverkhlegkikh letatelnykh apparatov [Videoteplovizionny control of gas with microlights]. Sovremennye problemy nauki $i$ obrazovaniia, 2014, no.3, pp.49-55.

39. Vaganova N. Mathematical model of testing of pipeline integrity by thermal fields. Applications of Mathematics in Engineering and Economics (AMEE'14), 2014, vol.1631, pp.37-41. DOI: 10.1063/1.4902455

40. Kaznacheev I. Na territorii riska [At risk]. Truboprovodnyi transport nefti, 2013, no.6, pp.30-31.

\section{Библиографический список}

1. Епифанцев Б.Н., Пятков А.А., Федотов А.А. Концепция обеспечения безопасной работы магистральных трубопроводов в условиях внешних воздействий // Безопасность труда в промышленности. 2013. - № 12. - С. 42-49.

2. Цвяк А.В. Экологические последствия несанкционированных врезок в нефтепроводы и методы борьбы с ними // Вестник Оренбургского государственного университета. - 2015. - № 10 (185). C. 445-447.

3. Vtorushina A.N., Anishchenko Y.V., Nikonova E.D. Risk assessment of oil pipeline accidents in special climatic conditions // IOP Conf. Series: Earth and Environmental Science 66 (2017) 012006. Ecology and safety in the technosphere: All-Russian research-to-practice conference, 6-7 March 2017. - Yurga, 2017. DOI: $10.1088 / 1755-1315 / 66 / 1 / 012006$

4. Нелегальные врезки в нефтепроводы остаются нерешаемой проблемой для правоохранителей и законодателей [Электронный ресурc]. - URL: hpps://versia.ru/ nelegalnye-vrezki-v-nefteprovody-ostayutsyane-reshaemoj-problemoj-dlya-pravooxraniteleji-zakono-datelej/ (дата обращения: 10.08.2018).

5. Безопасность магистральных трубопроводов в условиях террористических угроз: прогнозные оценки / В.А. Комаров, 3.В. Семенова, Е.М. Михайлов, А.А. Нигрей, Д.А. Бронников // Вестник Пермского национального исследовательского политехнического университета. Геология. Нефтегазовое и горное дело. - 2018. - Т. 17, № 1.-C. 88-100. DOI: 10.15593/2224-9923/2018.1.8

6. Годовой отчет о деятельности Федеральной службы по экологическому, технологическому и атомному надзору в 2016 году. - М., 2017. - 397 с.

7. Проект доклада о правоприменительной практике контрольно-надзорной деятельности в Федеральной службе по экологическому, технологическому и атомному надзору при осуществлении федерального государственного надзора в области промышленной безопасности за 2017 год. - М., 2018. - 66 с.

8. Фомин К. Сколько нефтеразливов слишком много для Британского музея? [Электронный pecypc]. - URL: http://www.greenpeace.org/russia/ru/news/blogs/ green-planet/blog/61117/ (дата обращения: 10.08.2018).

9. В решении проблемы разливов нефти наметился прогресс [Электронный ресурс]. URL: http://www.greenpeace.org/russia/ru/ news/2018/oil-0323/ (дата обращения: 10.08.2018). 
10. Савина А.В. Анализ риска аварий при обосновании безопасных расстояний от магистральных трубопроводов сжиженного углекислого газа до объектов с присутствием людей: дис. ... канд. техн. наук. - М.: ЗАО НТЦ ПБ, 2013. $121 \mathrm{c}$.

11. Модель формирования тепловых изображений подстилающей поверхности охранных зон магистральных продуктопроводов: Отчет о НИР (заключительный) № ГР 115050610098 / СибАДИ; рук. Д.С. Бронников; 3.В. Семенова, Р.В. Борисов, В.А. Комаров, А.А. Нигрей, C.С. Жумажанова, Н.Н. Нигрей. Омск, 2017. - 217 с.

12. Lou Z., Liu H., Hu M. A general survey on technological developments of oil leakage detection over the past decade // Applied Informatics and Communication. - 2011. - Vol.31. - P. 16-22. DOI: 10.1007/978-3-642-23214-5_79

13. Summary of detection and location for oil and gas pipeline leak / L. Wang [et al.] // 25 th Chinese Control and Detection Conference. - 2013. - № 656. - P. 821-826. DOI: 10.1109/CCDC.2013.6561035

14. Leakage detection using fiber optics distributed temperature monitoring / M. Nikles, B. Vogel, F. Briffod, S. Grosswig, F. Sauser, S. Luebbecke, A. Bals, T. Pfeiffer // $11^{\text {th }}$ SPIE Annual International Symposium on Smart Structures and Materials, March 14-18, 2004. - San Diego. - 2004. - Vol. 5384. P. 18-25. DOI: 10.1117/12.5400270

15. Duckworth G.L., Ku E.M. OptaSense (R) distributed acoustic and seismic sensing using COTS fiber optic cables for Infrastructure Protection and Counter Terrorism // Sensors, and command, control, communication, and intelligence (C3I) Technologies for homeland Security and homeland defense. 2013. - Vol. 8711, № UNSP 871106. DOI: $10.1117 / 12.2017712$
16. Duan L. Thermal noise-limited fiberoptic sensing at infrasonic frequencies // IEEE Journal of Quantum Electronics. 2015. - Vol. 51, № 2. - P. 1-6. DOI: 10.1109/JQE.2014.2384914

17. Суворова Е. Вне зоны доступа // Трубопроводный транспорт нефти. - 2012. № 6. - С. 34-35.

18. Волоконно-оптическая система мониторинга протяженных объектов (нефтепроводов) на основе когерентного рефлектометра / Е.Т. Нестеров, К.В. Марченко, B.Н. Трещиков, А.В. Леонов // T-Comm: телекоммуникации и транспорт. - 2014. № 1. - C. 25-28.

19. Klar A., Linker R. Fiber optic sensing optical fibers detect funnel-digging [Электронный ресурс] // Laser Focus World: Laser, Photonics, Optics News \& Technology Advances. - URL: http://www.laserfocusworld.com/articles/print/volume-45/issue-4/worldnews/fiber-optic-sensing-optical-fibers-detect-tunnel-digging.html/ (дата обращения: 10.08.2018).

20. Шеховцов А.В., Мансуров М.Н., Голубин С.И. Экспериментальное исследование волоконно-оптического метода обнаружения утечек из нефтегазопроводов // Трубопроводный транспорт: теория и практика. - 2015. - № 6 (52). - С. 30-35.

21. Шестаков Р.А., Ганеева Л.К., Ганеева Л.К. Анализ волоконно-оптических методов обнаружения утечек в трубопроводах // Труды РГУ нефти и газа имени И.М. Губкина. - 2015. - № 2 (279). С. 56-64.

22. Сейсмические шумы индустриального города / В.Е. Коридалин [и др.] // ДАН CCCР. - 1985. - Т. 280, № 5. - С. 1094-1097.

23. Кузнецов В.А., Цуканов В.Н., Яковлев М.Я. Волоконно-оптические информационно-измерительные системы // Высокие технологии в промышленности России (материалы и устройства функциональной электроники 
микрофотоники): материалы XII Междунар. науч.-техн. конф. / ОАО ЦНИТИ «Техномаш». - М., 2006. - С. 342-349.

24. Wang J., Han J. A new noise suppression algorithm for optical fiber temperature surveillance of heavy oil thermal recovery well // International Conference on Optical Instruments and Technology: Optical Sensors and Applications. - 2011. - Vol. 8199, № 81991. DOI: 10.1117/12.906604

25. Wu H., Li X., Peng Z. A novel intrusion signal processing method for phase-sensitive optical time-domain reflectometry (Phi-OTDR) // 23 RD International conference on Optical Fibre Sensors. - 2014. - Vol. 9157, № 91573. DOI: $10.1117 / 12.2058503$

26. Епифанцев Б.Н., Пятков А.А. Предупреждение чрезвычайных ситуаций на магистральных продуктопроводах. Часть 1. Обнаружение несанкционированных вторжений в охранную зону продуктопровода: монография. - Омск: Изд-во СибАДИ, 2013. - $122 \mathrm{c}$.

27. Оноприюк В. Ангарский излом // Трубопроводный транспорт нефти. 2013. - № 6. - С. 32-38.

28. Звежинский С.C. Периметровые маскируемые сейсмические средства обнаружения // Специальная техника. 2004. - №3. - C. 26-37.

29. Боровский А.С., Тарасов А.Д. Общая математическая модель системы физической защиты объектов // Вестник компьютерных и информационных технологий. - 2011. - №10. - С. 21-29.

30. Concept of data processing in multisensor system for perimeter protection / R. Dulski [et al.] // Conference of Sensors, and Command, Control, Communications, and Intelligence (C3I) Technologies for Homeland Security and Homeland Defence X. - 2011. - Vol. 8019, № 8019-35. DOI: $10.1117 / 12.883965$
31. Епифанцев Б.Н., Пятков А.А., Копейкин С.А. Мультисенсорные системы мониторинга территорий ограниченного доступа: возможность видеоаналитического канала обнаружения вторжений // Компьютерная оптика. 2016 - - T. 40, № 1. - C. 121-129. DOI: 10.18287/2412-6179-2016-40-1-121-129

32. Epifantsev B.N. An acoustic method for diagnostics of the state of underground pipelines: new possibilities // Russian Journal of Nondestructive Testing. 2014. - Vol. 50, № 5. - P. 254-257. DOI: $10.1134 / \mathrm{S} 1061830914050039$

33. Epifantsev B.N., Pyatkov A.A., Fedotov A.A. Evaluation of the sensitivity of a vibroacoustic detection system for local disturbances of trunk pipeline environmental parameters // Russian Journal of Nondestructive Testing. 2015. - Vol. 51, № 2. - P. 70-78. DOI: $10.1134 / \mathrm{S} 1061830915020035$

34. Giurgintin V. Structural health monitoring with piezoelectric wafer active sensors. - New-York: Academic Press, 2007. $-760 \mathrm{p}$.

35. Епифанцев Б.Н. Дистанционная диагностика подземных трубопроводов по тепловому излучению // Дефектоскопия. 2014. - № 3. - C. 28-39.

36. Врагова Е.В., Скляров Л.А. Обнаружение утечек газа из магистральных газопроводов в тепловом поле излучения земной поверхности // Вестник НГУ. Серия: Информационные технологии. - 2009. № 4. - C. 73-80.

37. Mucsi L. Application of GIS and aerial thermal image processing methods to solve environmental problems of the oil industry [Электронный pecypc]. - URL: http://www.geo.u-szeged.hu/web/sites/default/ files/publikaciok/ML/57.pdf/ (дата обращения: 10.08.2018).

38. Видеотепловизионный контроль состояния газопроводов с использованием 
сверхлегких летательных аппаратов / Л.Т. Кретов [и др.] // Современные проблемы науки и образования. - 2014. № 3. - C. 49-55.

39. Vaganova N. Mathematical model of testing of pipeline integrity by thermal fields //
Applications of Mathematics in Engineering and Economics (AMEE'14). - 2014. Vol. 1631. - P. 37-41. DOI: 10.1063/1.4902455 40. Казначеев И. На территории риска // Трубопроводный транспорт нефти. - 2013. № 6. - C. 30-31.

Please cite this article in English as:

Komarov V.A., Semenova Z.V., Bronnikov D.A., Nigrei A.A. About the structure of the system of physical protection of main pipelines against intended threats. Perm Journal of Petroleum and Mining Engineering, 2019, vol.19, no.1, pp.87-100.DOI: $10.15593 / 2224-9923 / 2019.1 .7$

Просьба ссылаться на эту статью в русскоязычных источниках следующим образом:

О структуре системы физической защиты магистральных трубопроводов от преднамеренных угроз / В.А. Комаров, 3.В. Семенова, Д.А. Бронников, А.А. Нигрей // Вестник Пермского национального исследовательского политехнического университета. Геология. Нефтегазовое и горное дело. - 2019. - Т.19, №1. - С.87-100. DOI: $10.15593 / 2224-9923 / 2019.1 .7$ 